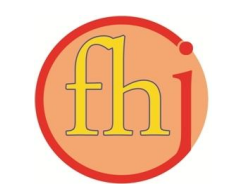

Faletehan Health Journal, 5 (2) (2018) 77-83

https://journal.Ippm-stikesfa.ac.id

ISSN 2088-673X| e-ISSN 2597-8667

\title{
Hubungan Pengetahuan dan Sikap dengan Perilaku Caring Perawat di Rumah Sakit
}

\author{
Sri Rahayu ${ }^{1 *}$, Sulistiawati ${ }^{1}$ \\ 1Program Studi Ilmu Keperawatan STIKes Faletehan Serang, Banten, Indonesia \\ *Corresponding Author: s_rahayu_13@yahoo.co.id
}

\begin{abstract}
Abstrak
Caring merupakan tindakan keperawatan yang mengedepankan kepedulian perawat terhadap klien. Selain itu, caring menjadi inti dari asuhan keperawatan. Penelitian ini bertujuan untuk mengetahui faktor-faktor yang berhubungan dengan perilaku caring perawat. Penelitian ini menggunakan metode kuantitatif dengan desain cross sectional. Penelitian dilakukan di Rumah Sakit dr.Dradjat Prawiranegara Serang dengan jumlah sampel 51 responden. Hasil penelitian menunjukan tidak ada hubungan antara pendidikan dengan perilaku caring perawat ( $p$ value $=0,264$ ). Sedangkan pengetahuan dan sikap perawat memiliki hubungan yang signifikan dengan perilaku caring ( $p$ value $\varangle, 001$ ). Perilaku caring yang baik dapat dipengaruhi oleh pengetahuan dan sikap perawat yang baik tentang caring. Perawat yang memiliki pengetahuan dan sikap yang baik menjadikan perilaku caring perawat menjadi baik pula.
\end{abstract}

Kata Kunci: Pengetahuan, Perawat, Perilaku Caring, Sikap

\begin{abstract}
Caring is a nursing action that puts the nurse caring towards the clien. In addition, caring to be the core of nursing care. This study aimed to determine factors associated with caring behavior of nurses. This study design was quantitative with cross sectional. This study was conducted at dr.Dradjat Prawiranegara Serang Hospital with 51 respondents. The statistical test showed that education level of nruse was not significant associated with caring behavior ( $p$ value 0.264 ), while knowledge and attitude of caring were significantly associated ( $p$ value $\varangle, 001$ ). Caring behaviour can be affected by knowledge and attitude of nurse. Nurses who have good knowledge and attitude made good caring behaviours too. Keywords: Attitude, Caring Behaviors, Knowledge, Nurse
\end{abstract}




\section{Pendahuluan}

Mutu pelayanan keperawatan sangat mempengaruhi kualitas pelayanan kesehatan bahkan menjadi salah satu faktor penentu citra institusi pelayanan kesehatan salah satunya di rumah sakit. Peningkatan mutu pelayanan keperawatan ini didukung oleh pengembangan teori-teori keperawatan, salah satunya adalah teori caring, yang didukung oleh Deklarasi Perawat Indonesia yang menyatakan bahwa kunci dalam meningkatkan kualitas pelayanan keperawatan adalah dengan menekankan perilaku caring (Kemenkes RI, 2018).

Caring merupakan tindakan perawat yang menunjukan kasih sayang, empati serta ikhlas dalam merawat pasien. Perilaku caring perawat ini bertujuan untuk memberikan asuhan keperawatan melalui suatu pendekatan yang berorientasi pada kepedulian perawat terhadap klien, dimana perilaku caring perawat ini sesuai dengan tuntutan masyarakat yang mengharapkan pelayanan kesehatan yang baik dan berkualitas. Sehingga jika perilaku caring ini diterapkan dengan baik maka klien akan merasa puas dan akan berdampak pada peningkatan mutu pelayanan keperawatan (Watson, 2008).

Di Indonesia, caring menjadi salah satu penilaian penting bagi masyarakat dalam memanfaatkan pelayanan kesehatan, namun sayangnya di Indonesia perilaku caring tersebut masih terbilang rendah. Hasil penelitian yang dilakukan oleh Usman yang dilakukan di lima kota besar Indonesia, ditemukan 9 poin permasalahan, salah satunya adalah sebanyak sebagian besar pasien mengeluh terhadap sikap perawat yang kurang ramah, kurang simpatik dan jarang tersenyum (Apriyanti, 2009). Penelitian lain Mailani \& Fitri (2017) di RSUD dr.Rasidin Padang yang menunjukkan sebagian besar pasien merasa tidak puas terhadap pelayanan keperawatan yang diberikan dikarenakan perilaku caring perawat yang kurang. Hal ini serupa dengan penelitian yang dilakukan di Ruang Kelas III Rumah Sakit Immanuel Bandung yang menunjukkan sebesar $21,3 \%$ klien yang merasa tidak puas terhadap pelayanan keperawatan yang disebabkan oleh perilaku caring perawat yang rendah (Hutapea, Dedi \& Elias ,2013). Penelitian diatas menunjukkan bahwa perilaku caring perawat di Indonesia masih terbilang rendah.
Rendahnya perilaku caring tersebut disebabkan oleh beberapa faktor. Gibson (1987) dalam (Faizin \& Winarsih, 2008) mengatakan ada tiga faktor yang dapat mempengaruhi perilaku caring perawat yaitu faktor individu yang terdiri dari pengetahuan dan keterampilan, latar belakang pendidikan, dan demografis. Faktor psikologi yang terdiri dari sikap, kepribadian, belajar dan motivasi. Faktor organisasi yang terdiri dari sumber daya, pelatihan dan pengembangan, imbalan atau penghargaan, pembuat keputusan, pengambilan risiko dan kerja sama. Pendidikan termasuk salah satu faktor individu yang mempengaruhi perawat dalam berperilaku caring. Pendidikan sangat penting bagi perawat untuk membangun perilaku caring.

Selain pendidikan, yang termasuk dalam faktor individu selanjutnya adalah pengetahuan. Pengetahuan merupakan hal yang mendasari perawat dalam mengaplikasikan perilaku caring. Semakin tinggi pengetahuan perawat terhadap caring maka harapannya perawat akan semakin tahu sikap yang seperti apa yang bisa menunjukkan dirinya untuk berperilaku caring terhadap klien. Asumsi ini didasarkan karena perawat yang memiliki tingkat kognitif tentang caring yang baik mempunyai landasan teori yang cukup untuk dirinya dalam mempraktekan caring. Hasil penelitian di RSU dr.H Koesnadi Bondowoso menunjukkan hasil bahwa terdapat hubungan antara tingkat kognitif perawat tentang caring dengan aplikasi praktek caring (Bondowoso, Prabowo, Ardiana, \& Wijaya, 2014).

Sikap perawat dalam menyikapi caring juga memberikan pengaruh terhadap perilaku caring perawat. Hal ini didasari oleh perawat yang menyikapi caring secara positif akan mendukung semua kegiatan yang berkaitan dengan caring dan akan mudah dalam menerapkan perilaku caring, begitu pula sebaliknya. Hasil penelitian yang dilakukan di ruang rawat inap kelas III bangsal barokah dan inayah RS PKU Muhammadiyah Gombong menunjukkan terdapat hubungan antara sikap perawat tentang caring dengan perilaku caring perawat (Ramadhan, 2017).

Caring secara umum diartikan sebagai suatu kemampuan seseorang dalam berdedikasi kepada orang lain, memberikan perhatian, ikut merasakan apa yang orang lain rasakan dan berbagi cinta serta kasih sayang kepada orang lain. Caring mempengaruhi cara berpikir, perasaan dan 
Faletehan Health Journal, 5 (2) (2018) 77-83 https://journal.Ippm-stikesfa.ac.id ISSN 2088-673X| 2597-8667

perbuatan seseorang, selain itu caring juga mempelajari berbagai macam filosofi dan etis perspektif (Perry \&Potter, 2005).

Perilaku caring perawat diruang kelas III cenderung kurang maksimal, dikarenakan jumlah pasien yang tidak seimbang dengan jumlah perawat. Hal ini dibuktikan oleh hasil studi pendahuluan yang dilakukan peneliti di Rumah Sakit dr.Dradjat Prawiranegara yang menunjukkan tingginya jumlah pasien yang dirawat dibandingkan dengan kapasitas. Kapasitas ruang rawat inap penyakit dalam dan bedah kelas III adalah 102 tempat tidur dengan rata-rata jumlah pasien perbulan dalam 3 bulan terakhir adalah 502 pasien. Survey kepuasan menurut persepsi pasien dan keluarga adalah sebesar $65 \%$. Hasil wawancara dari 10 orang pasien dan keluarga pasien didapatkan sebanyak 4 orang merasa puas dengan pelayanan keperawatan, sementara sebanyak 6 orang mengatakan belum puas terhadap pelayanan keperawatan yang diberikan dikarenakan sikap perawat yang kurang ramah, kurang cepat tanggap disaat pasien memerlukan bantuan dan jarang tersenyum.

Hasil observasi yang dilakukan peneliti mengenai perilaku caring perawat menunjukkan masih kurang maksimal. Hasil observasi didapatkan perawat masih lebih banyak berfokus pada penyembuhan penyakit pasien, sedangkan kebutuhan psikologis dan spiritual pasien masih belum menjadi perhatian. Selain itu, hasil observasi juga menemukan sikap perawat yang kurang ramah dengan pasien dan keluarga pasien serta perawat yang kurang cepat dalam memberikan pelayanan terhadap pasien. Hasil wawancara dengan 10 orang perawat sebanyak 4 perawat mampu mengetahui dan memahami caring, sedangkan 6 perawat belum mampu mengetahui caring.

\section{Metode Penelitian}

Penelitian ini menggunakan metode kuantitatif dengan desain cross sectional. Penelitian dilakukan pada bulan Mei-Juni di Ruang Rawat Inap Penyakit Dalam dan Bedah kelas III Rumah Sakit dr. Drajat Prawiranegara Serang tahun 2018. Populasi pada penelitian ini adalah perawat pelaksana sejumlah 51 orang dengan teknik pengambilan sampel menggunakan total sampling. Pengumpulan data penelitian dilakukan dengan menggunakan kuesioner pengetahuan, sikap dan perilaku caring. Semua pertanyaan dan pernyataan dalam kuesioner telah dilakukan uji validitas dan reliabilitas. Analisis data menggunakan analisis univariat dan bivariat dengan uji statistic chi square dengan batas kemaknaan $\alpha=0,05$.

\section{Hasil dan Pembahasan}

\section{Gambaran Pendidikan, Pengetahuan, Sikap dan Perilaku Caring Perawat.}

Hasil penelitian tentang pendidikan, pengetahuan, sikap dan perilaku caring perawat di ruang penyakit dalam dan bedah kelas III Rumah sakit dr.Dradjat Prawiranegara Serang digambarkan pada table 1 .

Tabel.1 menunjukkan bahwa sebagian besar perawat berpendidikan Diploma (76,5\%), memiliki pengetahuan baik (52,9\%), dan memiliki sikap positif $(58,8 \%)$. Dalam hal perilaku caring, perawat rumah sakit dr.dradjat Prawiranegara juga memiliki perilaku caring yang baik $(56,9 \%)$.

Hasil penelitian menunjukkan sebagian besar responden memiliki perilaku caring yang baik. Hal ini serupa dengan penelitian yang dilakukan oleh Armilah (2016) yang menunjukan perilaku caring diruang penyakit dalam dan bedah kelas III sebagian besar responden yang diteliti memiliki perilaku caring yang baik $(71,8 \%)$ responden.

Perilaku merupakan suatu respon seseorang yang ditunjukan karena adanya suatu stimulus atau rangsangan dari luar (Notoatmodjo, 2010). Perilaku merupakan respon terbuka dari seseorang dalam bentuk tindakan yang nyata sehingga dapat diamati (Fitriani, 2011). Berdasarkan hasil observasi menunjukan bahwa perawat memperlakukan pasien dengan baik dan sopan, memberikan kesempatan kepada pasien untuk bertanya, dan menjawab pertanyaan pasien dengan jelas.

Tabel 1 :Distribusi frekuensi pendidikan, pengetahuan, sikap dan perilaku caring perawat $(n=51)$

\begin{tabular}{lcc}
\hline \multicolumn{1}{c}{ Variabel } & F & \% \\
\hline Pendidikan & & \\
D3 keperawatan & 39 & 76.5 \\
S1 Keperawatan & 12 & 23,5 \\
\hline Pengetahuan & & \\
$\quad$ Baik & 27 & 52,9 \\
$\quad$ Kurang Baik & 24 & 47,1 \\
\hline Sikap & & \\
$\quad$ Positif & 30 & 58,8 \\
$\quad$ Negatif & 21 & 41,2 \\
\hline
\end{tabular}




$\begin{array}{lll}\text { Perilaku Caring } & & \\ \text { Caring baik } & 29 & 56,9 \\ \text { Caring kurang baik } & 22 & 43,1\end{array}$

Perawat selalu memeriksa kembali nama pasien serta meminta izin dan menjelaskan tindakan keperawatan yang akan dilakukan. Perawat memperhatikan prinsip keamanan dalam melakukan tindakan keperawatan, serta memberikan pendidikan kesehatan mengenai penyakit pasien. Hal ini senada dengan hasil penelitian yang dilakukan oleh Ramadhan (2017) yang menunjukan bahwa sebagaian besar responden yang diteliti memiliki perilaku caring yang baik.

\section{Hubungan Pendidikan Dengan Perilaku Caring Perawat}

Hubungan pendidikan dengan perilaku caring perawat di ruang rawat inap penyakit dalam dan bedah kelas III rumah sakit dr. Dradjat Prawiranegara Serang tahun 2018 digambarkan dalam tabel 2.

Berdasarkan tabel 2 diperoleh hasil bahwa dari 39 responden yang berpendidikan D3 keperawatan yang memiliki perilaku caring baik sebanyak 20 orang $(51,3 \%)$ dan perilaku caring kurang sebanyak 19 orang $(48,7 \%)$. Sedangkan dari 12 responden yang berpendidikan S1 keperawatan memiliki perilaku caring yang baik sebanyak 9 orang $(75,0 \%)$ dan sebanyak 3 orang $(25,0 \%)$ memiliki perilaku caring yang kurang. Hasil uji statistik chi square dengan tingkat kepercayaan 95\% diperoleh nilai $p$ value sebesar $0,264(p>\alpha)$ yang berarti tidak terdapat hubungan antara pendidikan dengan perilaku caring perawat pelaksana.

Berdasarkan hasil penelitian didapatkan bahwa sebagian besar responden yang diteliti berpendidikan terakhir D3 keperawatan. Hasil analisis juga menunjukan bahwa sebagian besar dari mereka memiliki perilaku caring baik lebih banyak. Hasil analisis menunjukkan tidak terdapat hubungan antara pendidikan dengan perilaku caring perawat. Hal ini menunjukan bahwa tingkat pendidikan perawat tidak mempengaruhi perilaku caring perawat pelaksana diruang penyakit dalam dan bedah kelas III. Hasil penelitian ini sejalan dengan penelitian (Murtianingrum, 2015) yang menunjukkan bahwa sebagian besar responden memiliki pendidikan terakhir D3 keperawatan dan memiliki perilaku caring yang baik. Hasil analisis juga menunjukan bahwa tidak terdapat hubungan antara pendidikan dengan perilaku caring perawat.

Tabel. 2: Hubungan pendidikan dengan perilaku caring Perawat $(n=51)$

\begin{tabular}{|c|c|c|c|c|c|c|c|}
\hline \multirow[t]{3}{*}{ Pendidikan } & \multicolumn{4}{|c|}{ Perilaku caring } & \multirow{2}{*}{\multicolumn{2}{|c|}{ Total }} & \multirow{3}{*}{$P$ Value } \\
\hline & \multicolumn{2}{|c|}{ Caring Baik } & \multicolumn{2}{|c|}{ Caring Kurang } & & & \\
\hline & $\mathrm{F}$ & $\%$ & $\mathrm{~F}$ & $\%$ & $\mathrm{~F}$ & $\%$ & \\
\hline D3 keperawatan & 20 & 51,3 & 19 & 48,7 & 39 & 100,0 & 0,264 \\
\hline S1 keperawatan & 9 & 75,0 & 3 & 25,0 & 12 & 100,0 & \\
\hline Total & 29 & 56,9 & 22 & 43,1 & 51 & 100,0 & \\
\hline
\end{tabular}

Tabel. 3: Hubungan pengetahuan dengan perilaku caring perawat $(n=51)$

\begin{tabular}{|c|c|c|c|c|c|c|c|c|}
\hline \multirow[t]{3}{*}{ Pengetahuan } & \multicolumn{4}{|c|}{ Perilaku caring } & \multirow{2}{*}{\multicolumn{2}{|c|}{ Total }} & \multirow{3}{*}{$P$ Value } & \multirow[b]{3}{*}{$O R$} \\
\hline & \multicolumn{2}{|c|}{ Caring Baik } & \multicolumn{2}{|c|}{ Caring Kurang } & & & & \\
\hline & $\mathrm{F}$ & $\%$ & $\mathrm{~F}$ & $\%$ & $\mathrm{~F}$ & $\%$ & & \\
\hline Baik & 25 & 92,5 & 2 & 7,4 & 27 & 100,0 & 0,000 & 62,5 \\
\hline Kurang & 4 & 16,7 & 20 & 83,3 & 24 & 100,0 & & \\
\hline Total & 29 & 56,9 & 22 & 43,1 & 51 & 100,0 & & \\
\hline
\end{tabular}

Tabel. 4: Hubungan Sikap Dengan Perilaku Caring Perawat ( $\mathrm{n}=51)$

\begin{tabular}{|c|c|c|c|c|c|c|c|c|}
\hline \multirow[t]{3}{*}{ Sikap } & \multicolumn{4}{|c|}{ Perilaku caring } & \multirow{2}{*}{\multicolumn{2}{|c|}{ Total }} & \multirow{3}{*}{$P$ Value } & \multirow{3}{*}{$O R$} \\
\hline & \multicolumn{2}{|c|}{ Caring Baik } & \multicolumn{2}{|c|}{ Caring Kurang } & & & & \\
\hline & $\mathrm{F}$ & $\%$ & $\mathrm{~F}$ & $\%$ & $\mathrm{~F}$ & $\%$ & & \\
\hline Positif & 22 & 71,0 & 9 & 16,4 & 30 & 100,0 & 0,000 & 28,0 \\
\hline Negatif & 2 & 10.0 & 18 & 90,0 & 21 & 100,0 & & \\
\hline
\end{tabular}


Faletehan Health Journal, 5 (2) (2018) 77-83 https://journal.Ippm-stikesfa.ac.id ISSN 2088-673X | 2597-8667

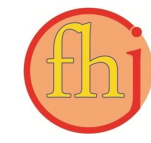

\begin{tabular}{lllllll}
\hline Total & 24 & 47,1 & 27 & 52,9 & 51 & 100,0 \\
\hline
\end{tabular}

Pendidikan merupakan sarana untuk mengubah sikap dan perilaku seseorang melalui belajar, diskusi, pelatihan dan lain sebagainya. Pendidikan sangat penting untuk mengubah pola pikir dan perilaku seseorang, jenjang pendidikan perawat mempengaruhi kualitas kinerja perawat itu sendiri karena semakin tinggi pendidikan perawat maka semakin luas pengetahuan dan wawasan seorang perawat sehingga nantinya akan berdampak pada perilaku perawat termasuk untuk beperilaku caring. Untuk membangun pribadi perawat yang berjiwa caring harus ditanamkan mulai sejak dini, dalam penyusunan kurikulum pendidikan keperawatan harus selalu memasukan unsur caring sehingga nantinya perawat sudah terbiasa berperilaku caring sejak dini (Watson, 2008).

\section{Hubungan Pengetahuan Dengan Perilaku Caring Perawat}

Hubungan pengetahuan dengan perilaku caring perawat di ruang rawat inap penyakit dalam dan bedah kelas III rumah sakit dr.Dradjat Prawiranegara Serang tahun 2018 ditunjukkan dalam table. 3.

Berdasarkan tabel 3 diperoleh hasil bahwa dari 27 responden yang berpengetahuan tentang caring yang baik memiliki perilaku caring yang baik sebanyak 25 orang $(92,5 \%)$ dan sebanyak 2 orang $(7,4 \%)$ yang memiliki perilaku caring yang kurang. Hasil uji statistik chi square dengan tingkat kepercayaan 95\% diperoleh nilai $\mathrm{p}$ value sebesar $0,000(\mathrm{p}<\alpha)$ yang berarti terdapat hubungan yang signifikan antara pengetahuan dengan perilaku caring perawat pelaksana. Nilai $\operatorname{Odd} \operatorname{Ratio}(O R)$ sebesar 62,5 yang artinya bahwa perawat dengan pengetahuan tentang caring yang baik memiliki peluang 62,5 kali lebih besar mempunyai perilaku caring yang baik dibanding perawat yang memiliki pengetahuan tentang caring yang kurang.

Hasil analisis hubungan antara pengetahuan dengan perilaku caring perawat menunjukan bahwa terdapat hubungan antara pengetahuan dengan perilaku caring perawat. Hal ini sejalan dengan peneliti Bondowoso dkk. (2014) yang menunjukan bahwa sebagian besar perawat memiliki tingkat kognitif tentang caring yang baik. Hasil analisis pada peneilitian tersebut juga menunjukan terdapat hubungan antara tingkat pengetahuan dengan perilaku caring perawat di RS
Koeswandi Bondowoso. Hasil penelitian ini juga sejalan dengan penelitian Pratiwi (2017) yang menunjukan bahwa sebesar $54,4 \%$ perawat memiliki pengetahuan yang baik mengenai caring dan hasil analisis didapatkan bahwa terdapat hubungan antara pengetahuan tentang caring terhadap aplikasi hubungan interpersonal perawat dengan pasien yang dimana hubungan interpersonal perawat pasien ini termasuk dalam point perilaku caring perawat.

Hal ini menandakan bahwa pengetahuan merupakan faktor yang mempengaruhi responden untuk berperilaku caring. Sesuai dengan teori yang dikemukakan oleh Gibson (1987) dalam (Faizin \& Winarsih, 2008) yang mengatakan bahwa faktor yang mempengaruhi perilaku caring perawat salah satunya yaitu pengetahuan. Pengetahuan merupakan hasil tahu seseorang yang didapatkan melalui belajar, pengalaman dan lain-lain. Pengetahuan perawat sangat mempengaruhi perilaku caring perawat karena perawat yang mempunyai pengetahuan tentang caring yang baik mempunyai landasan teori yang cukup untuk dirinya dalam mempraktikkan caring. Dengan demikian dapat disimpulkan bahwa semakin baik tingkat pengetahuan perawat terhadap caring, maka akan semakin baik juga perilaku caring perawat tersebut.

Dengan demikian, untuk menghasilkan pribadi perawat yang berjiwa caring pengetahuan menjadi faktor yang penting. Hasil penelitian ini juga sejalan dengan hasil penelitian Ramadhan (2017) yang menunjukkan bahwa pelatihan caring perawat mampu meningkatkan kemampuan dan keterampilan perawat untuk menerapkan caring, perawat yang memiliki kemampuan komunikasi yang baik dapat memberikan perilaku caring yang baik, pengalaman perawat dalam menghadapi pasien juga membuat perawat lebih terlatih dan terbiasa untuk berperilaku caring dan penghargaan atau reward dapat meningkatkan motivasi perawat untuk berperilaku caring.

\section{Hubungan Sikap dengan Perilaku Caring Perawat}

Hubungan sikap dengan perilaku caring perawat di ruang rawat inap penyakit dalam dan bedah kelas III rumah sakir dr.Dradjat Prawiranegara Serang tahun 2018 ditunjukkan dalam tabel.4. 
Berdasarkan tabel. 4 diperoleh hasil bahwa dari 30 responden yang memiliki sikap caring yang positif menunjukan perilaku caring yang baik sebanyak 22 orang $(71,0 \%)$ dan sebanyak 9 orang $(16,4 \%)$ yang memiliki perilaku caring yang kurang. Sedangkan dari 21 responden yang memiliki sikap caring yang negatif menunjukan perilaku caring yang kurang sebanyak 18 orang $(90,0 \%)$ dan sebanyak 2 orang $(10,0 \%)$ yang mempunyai perilaku caring baik. Hasil uji uji statistik chi square dengan tingkat kepercayaan 95\% diperoleh nilai $p$ value sebesar $0,000 \quad(p<\alpha)$ yang berarti terdapat hubungan yang signifikan antara sikap dengan perilaku caring perawat, dengan nilai Odd Ratio sebesar 28 yang artinya bahwa perawat dengan sikap caring yang positif memiliki peluang 28 kali lebih besar mempunyai perilaku caring yang baik dibanding perawat yang memiliki sikap yang negatif.

Berdasarkan hasil penelitian didapatkan data bahwa sebagian besar responden yang diteliti diketahui sebagian besar memiliki sikap caring yang positif. Hasil penelitian ini sejalan dengan penelitian yang dilakukan di Ruang Rawat Inap Kelas III Bangsal Barokah dan Inayah RS PKU Muhammadiyah Gombong yang menunjukan bahwa sebagian besar responden yang diteliti memiliki sikap yang positif terhadap caring (Ramadhan, 2017). Hasil analisis juga menunjukan bahwa sebagian besar perawat yang memiliki perilaku caring yang baik terjadi pada perawat yang memiliki sikap yang positif terhadap caring, sedangkan dari perawat yang memiliki sikap caring yang positif hanya sebagian kecil yang memiliki perilaku caring yang kurang.

Hasil analisis menunjukkan terdapat hubungan antara sikap dengan perilaku caring perawat pelaksana serupa dengan penelitian Ramadhan (2017) yang mengatakan bahwa sebesar $63,3 \%$ memiliki sikap yang positif terhadap caring dan dari hasil analisis didapatkan hasil bahwa terdapat hubungan yang signifikan antara sikap dengan perilaku caring perawat.

Sikap merupakan suatu reaksi perasaan seseorang terhadap suatu objek, reaksi tersebut bisa berupa perasaan mendukung atau tidak mendukung. Sikap perawat dalam menyikapi caring memberikan pengaruh terhadap perilaku caring perawat, hal ini didasari oleh perawat yang menyikapi caring secara positif akan mendukung semua kegiatan yang berkaitan dengan caring dan akan mudah dalam menerapkan perilaku caring, begitu pula sebaliknya. Gibson (1987) dalam (Faizin \& Winarsih, 2008) mengatakan bahwa sikap seseorang terhadap suatu objek akan mempengaruhi perilaku seseorang terhadap objek tersebut.Sikap caring perawat yang positif selain terbentuk dari pengetahuan yang baik dan juga didapatkan dari kebudayaan, lingkungan kerja dan lembaga pendidikan yang telah ditempuh perawat (Ramadhan, 2017).

Pada penelitian ini dapat menunjukan bahwa sikap merupakan faktor yang mendukung perawat untuk berperilaku caring. Sesuai dengan teori yang dikemukakan oleh Gibson (1987) dalam (Faizin \& Winarsih, 2008) yang mengatakan bahwa sikap merupakan salah satu faktor yang mempengaruhi perilaku caring perawat. Sikap merupakan tanggapan seseorang terhadap suatu objek. Dari hasil penelitian ini dapat diketahui bahwa sebagian besar responden bersikap positif terhadap caring yang artinya sebagian besar responden menganggap caring adalah suatu hal yang baik. Perawat diruang penyakit dalam dan bedah kelas III Rumah Sakit dr.Dradjat Prawiranegara memiliki sikap caring yang positif sehingga menghasilkan perilaku caring yang baik. Dapat disimpulkan bahwa semakin positif sikap perawat mengenai caring maka akan semakin baik pula perilaku caring perawat.

\section{Simpulan}

Perawat di Ruang Penyakit Dalam dan Bedah Kelas III Rumah Sakit dr.Dradjat Prawiranegara Kabupaten Serang memiliki perilaku caring yang baik, hal ini didukung oleh pengetahuan dan sikap yang baik pula dari perawat. Hasil penelitian menunjukkan ada hubungan antara pengetahuan dan sikap perawat dengan perilaku caring perawat, sedangkan pendidikan tidak ada hubungan yang signifikan antara pendidikan dengan perilaku caring perawat.

\section{Referensi}

Apriyanti M. (2009). Faktor-faktor Yang Berhubungan Dengan Perilaku Caring Perawat Di Ruang Perawatan Interna. Fakultas Kesehatan Masyarakat Universitas Sriwijaya.

Ardiana, A. Sahar, J. Gayatri, D. (2010). Hubungan Kecerdasan Emossional Perawat Dengan Perilaku Caring Perawat Pelaksana Menurut Persepsi Paien.Jurnal Keperawatan Indonesia.Vol 13, No. 3. 
Faletehan Health Journal, 5 (2) (2018) 77-83

https://journal.Ippm-stikesfa.ac.id ISSN 2088-673X | 2597-8667

http://www.lontar.ui.ac.id/file?file=digital/20 282484T\%20Anisah\%20Ardiana.pdf.

Armilah, S. (2015). Hubungan Stress Kerja Dengan Perilaku Caring Di Ruang Rawat Inap Kelas III RSUD dr.Dradjat Prawiranegara Kabupaten Serang. Skripsi tidak dipublikasikan.

Bondowoso, K., Prabowo, B. S., Ardiana, A., \& Wijaya, D. (2014). Hubungan Tingkat Kognitif Perawat tentang Caring dengan Aplikasi Praktek Caring di Ruang Rawat Inap RSU dr . H . Koesnadi Bondowoso ( The Correlation between Nurses Cognitive Level on Caring with Caring Practice Application in the Inpatient Unit RSU dr. E-Jurnal Pustaka Kesehatan, 2(1), 148-153.

Faizin, A., \& Winarsih. (2008). Hubungan Tingkat Pendidikan dan Lama Kerja Perawat dengan Kinerja Perawat di RSU Pandan Arang Kabupaten Boyolali. Berita Ilmu Keperawatan, 1(3), 137-142.

Fitriani, S. (2011). Promosi Kesehatan. Cetakan 1. Yogyakarta: Graha Ilmu.

Hutapea. A. K, Dedi Blacius, Elias Yuliana. (2013). Hubungan Perilaku Caring Perawat Dengan Tingkat Kepuasan Pasien Yang Dirawat di Ruangan Kelas III Rumah Sakit Immanuel Bandung. Jurnal Ilmu Kesehatan. 8, 383-392.

Kementerian Kesehatan RI. (2009). UndangUndang Republik Indonesia Nomor 44 Tahun 2009 Tentang Rumah Sakit, 1. https://doi.org/10.1017/CBO9781107415324. 004Tinggi, S., \& Kesehatan, I. (2017). Hubungan pengetahuan dan sikap caring dengan perilaku caring perawat pada pasien.

Mailani, F., \& Fitri, N. (2017). Hubungan Perilaku Caring Perawat Dengan Tingkat Kepuasan Pasien BPJS Di RSUD DR. Rasidin
Padang.Journal Endurance 2(2), 2(June), 203-208. https://doi.org/: http://dx.org/10.22216/jen.v2i2.1882.

Murtianingrum, B. (2015). Hubungan Tingkat Pendidikan Perawat Dengan Perilaku Caring Perawat Di Rumah Sakit Umum Daerah Panembanan Senopati Bantul. Skripsi Ilmu Keperawatan.

https://www.google.com/search?q=hubungan tingkatpendidikandenganprilakucaring.69i57. 10959j0j4\&.pdf

Notoatmodjo, S. (2007). Promosi Kesehatan dan Ilmu Perilaku. Jakarta: Rineka Cipta.

Notoatmodjo, S. (2010). Metodologi Penelitian Kesehatan. Edisi Revisi. Jakarta : Rineka Cipta Perry A.G \& Potter P.A. (2005). Fundamental Keperawatan Konsep, Proses dan Praktik, Edisi 4, Volume 1. Jakarta : EGC.

Pratiwi, L (2017). Hubungan Tingkat Pengetahuan Perawat Tentang Caring Terhadap Pencapaian Hubungan Interpersonal Perawat-Pasien Di Ruang Rawat Inap RS DKT Jember. Skripsi. http://repository.unej.ac.id/handle/123456789 184849.

Ramadhan, N,1 (2017). Hubungan Pengetahuan Dan Sikap Caring Dengan Perilaku Caring Perawat Pada Pasien. Skripsi Ilmu Keperawatan. http://elib.stikesmuhgombong.ac.id/709/1/IS NAENI\%20NUR\%20RAMADHAN\%20NI M.\%20A11300970.pdf.

Watson, J. (2008). Core concepts of Jean Watson 's theory of human caring/caring science. Textto Contexto Enferm, Florianópolis, 2008. 